\title{
Analysis of Occupational Diseases Occurring in Forestry and Wood Processing Industry in Slovakia
}

\section{Analiza pojavnosti profesionalnih bolesti u šumarstvu i drvnoprerađivačkoj industriji Slovačke}

\author{
Original scientific paper • Izvorni znanstveni rad \\ Received-prispjelo: 1. 2. 2011. \\ Accepted-prihvaćeno: 14. 7. 2011. \\ UDK: $630 * 79 ; 674$ \\ doi:10.5552/drind.2011.1104
}

\begin{abstract}
The scope of this paper is the analysis of occupational diseases occurred in forestry and wood processing industry (WPI) between 2000-2009. The aim of this analysis is to highlight the development of occupational diseases and the impact of selected factors on development trend. The basis for the analysis was the basic information on affected persons - gender, job, age and duration of exposure to harmful agents, as well as the information about specific diseases and factors that support the appearance of the disease. Data for the ten-year observation period were evaluated graphically and the correlation between the selected qualitative characteristics was determined by the method of contingency tables. An interesting result is the proportion of diseases among women in the WPI, which reaches nearly 40\%, in forestry where men are mostly harmed. The most often represented disease in forestry is vibration disease. The total share of the three types of this disease (vibration disease of joints, bones, tendons and muscles; disease of blood vessels and nerves; other vibration diseases and combined diseases caused by vibration) accounts for up to 52\% of all occupational diseases. In the wood processing industry the damage of workers' hearing was the most frequently occurring harm.
\end{abstract}

Key words: occupational diseases, forestry, wood industry

SAŽETAK • Cilj rada bio je prikazati analizu pojavnosti profesionalnih bolesti u šumarstvu i drvnoprerađivačkoj industriji (WPI) u razdoblju 2000 - 2009. godine u Slovačkoj. Svrha analize bila je naglasiti razvoj profesionalnih bolesti i utjecaj određenih činitelja na trend njihova razvoja. Analize se temelje na osnovnim podacima o oboljelima - na spolu, poslu, godinama starosti, trajanju izlaganja štetnim tvarima te na podacima o posebnim bolestima i činiteljima koji su pridonijeli pojavi bolesti. Podaci za desetogodišnje razdoblje prikazani su grafički, a analiza korelacije između određenih kvalitativnih obilježja napravljena je metodom kontingencijskih tablica. Zanimljiv je rezultat udjela oboljelih žena u drvnoprerađivačkoj industriji koji doseže gotovo $40 \%$, a u šumarstvu su oboljeli uglavnom muškarci. Najčešća bolest u šumarstvu jest bolest prouzročena izlaganjem vibracijama. Ukupan udio triju tipova te bolesti (bolesti zglobova, kostiju, tetiva i mišića; bolesti krvnih žila i živaca; drugih bolesti od

\footnotetext{
Authors are associate professor, assistant and associate professor at Faculty of Forestry, Technical University of Zvolen, Zvolen, Slovakia. ' Autori su izvanredni profesor, asistentica i izvanredni profesor Šumarskog fakulteta Tehničkog sveučilišta u Zvolenu, Zvolen, Slovačka.
} 
vibracija ili u kombinaciji s vibracijama) u svim profesionalnim bolestima iznosi $52 \%$. U drvnoprerađivačkoj je industriji najzastupljenija bolest oštećenje sluha radnika.

Ključne riječi: profesionalna bolest, šumarstvo, drvnoprerađivačka industrija

\section{INTRODUCTION}

1. UVOD

Current status of occupational diseases in the Slovak Republic can be characterized in terms of statistics as a positively evolving. It is confirmed by the information on the number of newly reported occupational diseases in 2008, when 201 cases were registered. Compared to 2007 (413 cases) it is a significant drop, particularly in terms of more negligible decrease in the number of workers in hazardous workplaces from 116,297 workers in 2007 to 115,825 workers in 2008, representing approximately $0.4 \%$ (Statistical Office of the Slovak Republic).

Forestry and wood processing industry affect these facts significantly. They are among the sectors with the highest risk of occupational diseases, work injuries, etc. Vibration, noise, long-term unilateral excessive workload of the body, but also diseases transmitted by wood ticks are regarded as the most important factors with the harmful effect on humans. The most common diseases transmitted by wood ticks (in the Slovak Republic Ixodes ricinus) are the Lyme disease and wood tick-borne encephalitis. Untreated, these diseases can have serious consequences.

The term vibration means the oscillating movement of bodies or mechanical continuum. Vibrations can be transmitted to the organism as a whole, or to its parts, especially to hands:

1. Overall vibration is transmitted to a seated or standing person from vibrating seat, floor or platform so that it causes intense vibration of the whole body.

2. Vibrations transmitted to the hands are transferred from the vibrating handle or other object held by hands, especially to hands of exposed persons $-\mathrm{e}$. g. vibrations transmitted to the workers from the handles of manual pneumatic tools, steering wheel, etc.

3. Vibrations that cause intense shivering of upper spine and head are regarded as vibrations transmitted in a special way. Vibrations from the seat are considered as overall vibrations.

In the case of workers engaged in logging, it is necessary to pay special attention to vibrations transmitted from a portable chain saw (PCHS) to hands. Negative synergistic effect of vibrations and cold may have the effect of white fingers disease. Untreated, the disease ends up in gangrene in many cases.

It is possible to eliminate the effects of vibrations on human body by appropriate work and rest regime, selection of appropriate anti-vibration gloves, and by the use of tools of appropriate age, technical conditions and maintenance. A relationship between vibrations level and the age of instrument used was shown only in 55 cases out of 107 portable chainsaws (Goglia and Žgela, 2003).
In addition to fixed hand tools, the sources of vibration in the wood processing industry are also woodworking machines, saws. Goglia and Grbac (2005) analyze the measurement results of the whole-body vibration transmitted to the frame saw operator during an ordinary working day. Vibration was measured in all operations performed during the normal frame saw working cycle. Frequency spectra were obtained for all measurements and the results were graphically presented according to the ISO 2631-1-1986 recommendations. The weighted r.m.s. acceleration was also calculated, and the duration of each single frame saw operation was measured. The energy-equivalent vibration level, corresponding to the total duration of exposure was calculated, too. Thus obtained values were compared with the daily exposure limits according to the ISO 2631-1-1997.

The noise is a side-effect of vibrations. It can be defined as any unwanted sound that causes an ugly or disruptive perception or harmful effect. The noise is directly harmful to the organ of hearing and causes permanent hearing loss if the sound level is higher than 85 $\mathrm{dB}(\mathrm{A})$. Above $130 \mathrm{~dB}(\mathrm{~A})$, adverse effects have already been observed on tissues (the pain threshold) and above $160 \mathrm{~dB}(\mathrm{~A})$ the drum damage occurs.

Occupational hearing loss occurs when the organ of hearing is continuously and repeatedly exposed to noise during work or working process. The core of occupational time-worn of hearing is a degenerative damage up to complete destruction of sensory cells of hearing organ by the noise with the subsequent damage of other elements inside the ear. The inception and severity of the occupational hearing disease depends on:

- character of noise,

- conditions of noise exposure,

- particular factors related to the exposed person.

OSHA (Occupational Safety and Health Administration) has set a maximum permissible average noise level of $90 \mathrm{~dB}(\mathrm{~A})$ per eight-hour working day. The permissible noise exposure rises to a maximum of 115 $\mathrm{dB}(\mathrm{A})$, a level that can be tolerated for only 15 minutes or less per day. A circular saw produces between 100 and $109 \mathrm{~dB}(\mathrm{~A})$, a medium-sized woodworking shop in full operation averages about $110 \mathrm{~dB}(\mathrm{~A})$, and a chain saw may peak at $130 \mathrm{~dB}(\mathrm{~A})$ (OSHA In Wellborn).

The Croatian scientists tried to reduce the effects of circular saw noise using a rubber damper (damping rubber-ring). The noise was analyzed using nine rolls - three of different diameter and three of different type. Due to the whistling sound, the blades without slots emitted very high sound pressure levels. There were no significant changes when the rubber damping-rings were used. The use of the rubber damping-rings on the samples with radial slots eliminates the whistling noise. The saws with copper corks did not emit a whistling noise at all and their aerodynamic noise was 2-3 $\mathrm{dB}(\mathrm{A})$ 
lower than the aerodynamic noise of the saws with radial slots (Beljo Lučić and Goglia, 2001).

During the noise loading measurement of the operator of the tractor, with additional striking rotary cultivator, at work in the cabin with open vent holes, in all the cases reported higher levels of noise were recorded than permitted by law. The highest values exceeding the maximum allowable noise levels were measured in the workplace of ŠS Námestovo - $89.2 \mathrm{~dB}(\mathrm{~A})$ (Klč and Radocha, 1998).

A common problem in both sectors is a disease of long-term, unilateral overloading of limbs. Occupational diseases caused by long-term, unilateral overloading affect the structure of the locomotor limb system - bones, joints, tendons, muscles, nerves and blood vessels. They are caused by various business activities associated with an overloading of limbs without providing time necessary for recovering. The inception of the disease depends on the factors at work and individual anatomo-functional characteristics of a worker related to the type and way of work performance.

A specific factor affecting the human health in the wood processing industry is dust generated by wood processing. The effect of dust on the human body depends on its physical, chemical and biological properties and its quantity in the air and respiratory activity (eg. strain). The dust particles are inhaled through the nose and mouth and some 40 to $50 \%$ of particles with the size of $0.02 \mathrm{~mm}$ are caught on the nose hairs, nose mucous membranes, mouth and in the upper respiratory tract. The upper respiratory system retains most particles larger than $0.005 \mathrm{~mm}$. Only the respirable dust, which is deposited in the tracheas and alveolars, gets into the lower respiratory tract. The dust also pe netrates into the conjunctival sac, settles on the skin and causes thecoryza and conjunctivitis, skin eczema, breathlessness and allergic reactions (Irša, 2010).

Dzurenda et al. (2010) analyzed the dust particles of oak wood that was cut with a frame saw with a narrow slice, before and after thermal modification. The sawdust of the thermally modified dry oak created in the sawing process consists of chip granularity ranging from $0.0412 \mathrm{~mm}$ to $3.6 \mathrm{~mm}$, whereas the unmodified oak wood chips sawdust consists of granularity in the range from $0.0448 \mathrm{~mm}$ to $12.1 \mathrm{~mm}$.

A new phenomenon, of which the inhabitants of Slovakia are already getting aware, is bioenergetics. For the workers in forestry this means, in terms of safe work, identification and definition of new risks (Suchomel and Belanová, 2009) and analysis of previously defined risks in this sphere. In the whole process of energetic chips production (from the establishment of plantations of fast-growing trees, their management, and energy management to their cutting), there is a wide range of risks: the risk of working with chemicals in the fertilization in case of small areas, the risk of accidents during trimming, but also during cutting by a cutter, and especially when using a portable chain saw, which is also physically demanding. It is therefore recommended only for small areas (Trenčiansky et al., 2007). In the processing of forest biomass, there are the risks such as the above mentioned noise, vibration, dust and the risk of accident and also the risks occurring in storing of and work with energy chips such as fungi, mold, dust, terpenes and many other allergens.

In solving issues related to safety and health of workers (SHW), the prevention plays an important role. The basis for applying this approach to ensure safety and health at workplace is knowledge, which is required not only at senior officer level, but also for workers. Therefore, based on a risk analysis, a proposal of preventive, organizational and control measures should be developed in the forestry practice and wood processing industry in the Slovak Republic. It is also necessary to make technical and design changes of machinery and equipment, changes in technology, procedures and regulations, particularly in the SHW-area.

\section{MATERIAL AND METHODS}

\section{MATERIJAL I METODE}

The data necessary for the purpose of occupational diseases analysis were obtained from the National Health Information Center. The information obtained is related to the occupational diseases recorded for the years 2000-2009 in Slovakia in the business activity (by NACE) 02 - Forestry, timber logging and related services and 20 - Manufacture of wood and wood and cork products, except furniture; straw products and products made of plaiting materials.

The database contains data categorized by:

- occupation of affected person,

- age of affected person,

- gender of affected person,

- specific disease,

- harmful agent,

- duration of exposure to the harmful factors.

They were sorted by year and the above mentioned business activities.

The biggest deficiency found in the obtained documents was the absence of some information for certain periods. There were no data mainly for 2003 and 2004, describing the duration of workers' exposure. The duration of exposure to a certain harmful factor plays an important role e.g. in the development of standards and subsequent compliance of work and rest regime, which is reflected in the number of occupational diseases, but also in the occurrence of accidents.

In the reports for the period 2000-2002 there was a lack of essential information about the harmful factor, exposure to which caused the occupational disease. The relevance of this information mainly lies in the effort to improve the state of SHW in Slovakia, primarily in the form of prevention, in the effort to increase the efficiency and to optimize the work processes and to ensure the return of the workforce, etc.

\subsection{Analytical works \\ 2.1. Analitički radovi}

For the reasons stated in the previous paragraph, the evaluation of occupational diseases was not simple. The essential information on duration of exposure had to 
Table 1 Example of Contingency Table

Tablica 1. Primjer tablice kontingencije

\begin{tabular}{|c|c|c|c|c|c|c|c|c|}
\hline \multirow{2}{*}{\multicolumn{2}{|c|}{$\begin{array}{l}\text { Factor } B \\
\text { Factor } A\end{array}$}} & \multicolumn{6}{|c|}{ Degrees of factor $B$} & \multirow[t]{2}{*}{$\sum$} \\
\hline & & \multirow{2}{*}{$\begin{array}{l}B_{1} \\
n_{11}\end{array}$} & \multirow{2}{*}{$\begin{array}{l}B_{2} \\
n_{12}\end{array}$} & \multirow{2}{*}{$\begin{array}{ll}\ldots \ldots \\
\ldots \ldots .\end{array}$} & \multirow{2}{*}{$\begin{array}{l}B_{\mathrm{j}} \\
n_{1 \mathrm{j}}\end{array}$} & \multirow{2}{*}{$\begin{array}{ll}\ldots \ldots . \\
\ldots \ldots .\end{array}$} & \multirow{2}{*}{$\begin{array}{l}B_{\mathrm{m}} \\
n_{1 \mathrm{~m}}\end{array}$} & \\
\hline \multirow{8}{*}{ 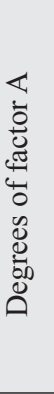 } & $A_{1}$ & & & & & & & $m_{1}$ \\
\hline & $A_{2}$ & $n_{21}$ & $n_{22}$ & $\cdots \cdots$ & $n_{2 \mathrm{j}}$ & $\ldots \ldots$ & $n_{2 \mathrm{~m}}$ & $m_{2}$ \\
\hline & . & . & . & & & & & . \\
\hline & . & . & . & & & & & . \\
\hline & $A_{\mathrm{i}}$ & $n_{\mathrm{i} 1}$ & $n_{\mathrm{i} 2}$ & $\ldots$. & $n_{\mathrm{ij}}$ & $\ldots$. & $n_{\mathrm{im}}$ & $m_{\mathrm{i}}$ \\
\hline & $\cdot$ & . & & & & & & . \\
\hline & . & . & & & & & & . \\
\hline & $A_{\mathrm{k}}$ & $n_{\mathrm{k} 1}$ & $n_{\mathrm{k} 2}$ & & $n_{\mathrm{kj}}$ & & $n_{\mathrm{km}}$ & $m_{\mathrm{k}}$ \\
\hline \multicolumn{2}{|l|}{$\sum$} & $n_{1}$ & $n_{2}$ & ..... & $n_{\mathrm{j}}$ & $\ldots .$. & $n_{\mathrm{m}}$ & $n$ \\
\hline
\end{tabular}

be analyzed separately for the "first" and "second" period. Similarly, the data about occupation had to be evaluated in two parts because of the occupation list. The database was evaluated in Excel charts. The results were compared cumulatively for the entire period, within the scope of specific business activities and years.

\subsection{Contingency table}

\subsection{Tablice kontingencije}

The method of Contingency Table was used to analyze the relationship between quality characters.

When there are two multipal qualitative factors $A, B$, of which the first occurs in the variations (degrees) $A_{1}, A_{2}, A_{3}, \ldots A_{\mathrm{k}}$ and the second in the variations (degrees) $B_{1}, B_{2}, B_{3} \ldots B_{\mathrm{m}}$, their sorting forms $k \times m$ contingency table as shown in Tab. 1.

The degree of dependence between the multiple qualitative factors $A, B$ is measured by comparing the actual frequencies in particular stages of the Contingency Table $n_{i j}$ with the expected multiplicity $n_{i j}^{\prime}$ assuming the independence of factors $A, B$. The expected dependences are calculated according to equation:

$$
n_{i j}^{\prime}=\frac{m_{i} \cdot n_{j}}{n}
$$

They are calculated by multiplying the marginal frequencies ( $m_{\mathrm{i}}$ for factor $A$ and $n_{\mathrm{j}}$ for $B$ factor) range divided by a set of $n$.

The basis for the calculation is the quantity $\chi^{2}$ (chi square), which is specified by the relationship:

$$
\chi^{2}=\sum_{i=1}^{k} \quad \sum_{j=1}^{m} \frac{\left(n_{i j}-n_{i j}^{\prime}\right)}{n_{i j}^{\prime}}
$$

The calculation of $\chi^{2}$ is done directly in the contingency table, where the expected frequencies $n_{i j}^{\prime}$ or the differences $\left(n_{i j}-n_{i j}^{\prime}\right)$ are recorded in each grade (box table) except the actual frequencies. Other symbols $n$, $k, m$ are known from the text.

The expected frequencies must also be calculated for the table boxes where the actual frequencies do not occur. The frequencies in the respective boxes enter the calculation of $\chi^{2}$ with the value

$$
\frac{\left(0-n_{i j}^{\prime}\right)^{2}}{n_{i j}^{\prime}}=n_{i j}^{\prime}
$$

The formula gives reliable results when the sample size is $n>40$. If any of the frequencies in the contingency table is less than 5, the appropriate correction must be made in order to make the result reliable. The most advantageous correction is the one proposed by Yates (Myslivec, 1957, in Šmelko and Wolf, 1977) residing that the value of 0.5 be added to the minimum frequency and the other frequencies be adjusted so as to keep the marginal frequencies unchanged. In the case that $20<n<40$ and any of the expected frequencies $n_{i j}^{\prime}$ is less than 5, the class in which the frequency is included should be merged with the neighboring (closest relative) class of $A$ or $B$ factor. For the range set $n<20$ this methodology should not be used at all.

Variable $\chi^{2}$ is the basis for a test of hypothesis about the independence of factors $A$ and $B$. Its small values argue in favor of the hypothesis, the large values against the hypothesis.

In practice, the compliance with the asymptotic distribution is considered to be sufficient if $a_{\mathrm{ij}}>5 \forall i, j$. If the $\chi^{2}>\chi_{(k-1)(m-1)}^{2}(\alpha)$, the hypothesis of independence of factors $A, B$ is rejected. The critical values of $\chi_{(k-1)}^{2}$ ${ }_{(m-1)}(\alpha)$ are tabulated, while $(k-1)(m-1)$ represent the number of degrees of freedom.

Sometimes the $\chi^{2}$ is also called the ratio of assurance. The value of $\chi^{2}$ variable tells whether the dependency between factors $A$ and $B$ could be regarded as statistically significant or not. It does not say anything, however, about the dependence degree of these factors. The degree of dependence can be expressed by a coefficient of correlation of two multiple qualitative factors $A, B$, which is calculated by the Čuprov formula (Urbach, In Šmelko and Wolf 1977):

$$
r_{A B}=\sqrt{\frac{\chi^{2}}{n \cdot \sqrt{(k-1) \cdot(m-1)}}}
$$

\section{RESULTS AND DISCUSSION} 3. REZULTATI I RASPRAVA

From the reports on occupational diseases, risk of occupational disease, professional poisonings and other health damages at work, we evaluated 505 illnesses in 


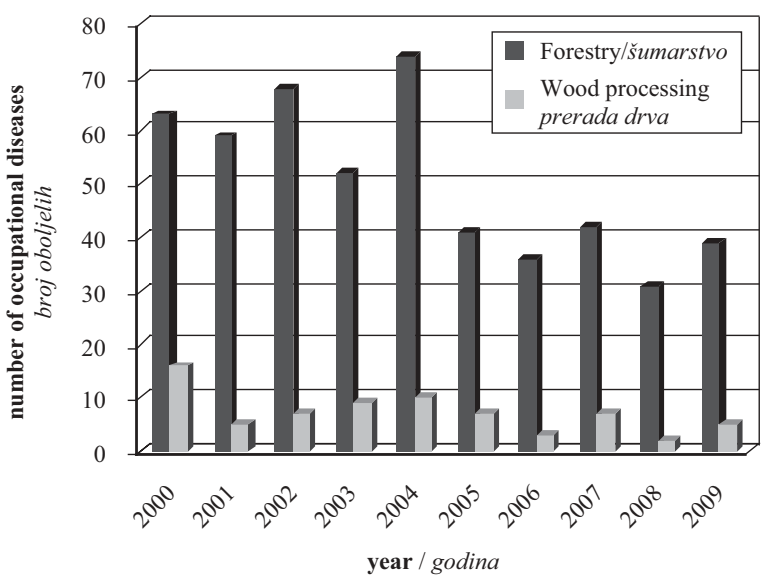

Figure 1 Frequency of occupational diseases classified by years

Slika 1. Pojavnost profesionalnih bolesti u promatranom razdoblju po godinama

business activity (NACE) 02 - Forestry, logging and related services and 71 diseases in business activities 20 Manufacture of wood and products of wood and cork, except furniture, manufacture of articles of straw, plaiting and suchlike materials for the period $2000-2009$.

The maximum number of diseases occurred in forestry in 2004 and in WPI in 2000. Interesting is the decrease in the occurrence of occupational diseases in the last five years (Fig. 1), i.e. since 2005 (mainly in forestry). Further annual development of diseases frequency has a fluctuating nature. In the future, however, it may be expected that occupational diseases frequency will have a decisively negative impact on this development as the way of performance of forest activities has changed in the Forests of Slovakia, the State Enterprise. They are now performed on contract basis, the non-employment arrangements with no possibility to relax and with newly adopted systemic measures (e.g. regular special medical examinations). In the WPI the highest number of occupational diseases was recorded in 2000. In 2004 the curve reached the second maximum and the trend is similar to forestry sector up to 2009. Like in forestry, an increase of occupational diseases can be expected.

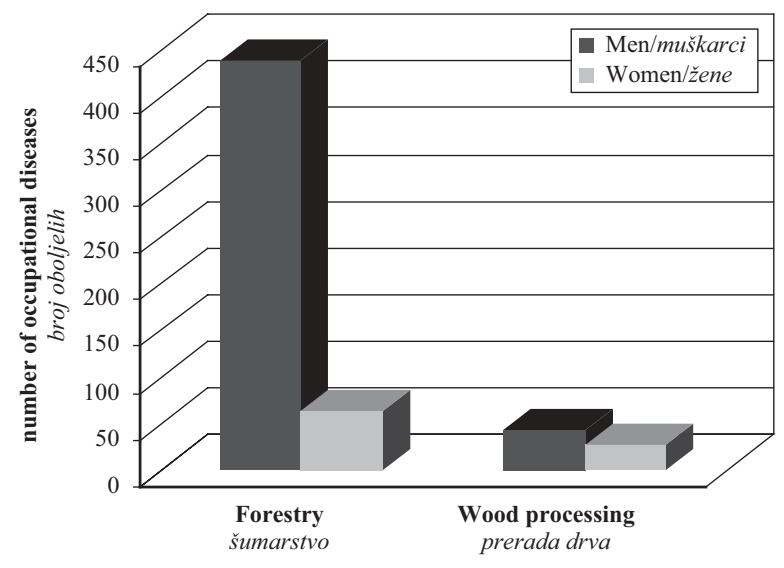

Figure 2 Frequency of occupational diseases in forestry and WPI classified by gender

Slika 2. Pojavnost profesionalnih bolesti u šumarstvu i drvnoprerađivačkoj industriji prema spolu

The disproportion in the number of occupational diseases in forestry classified by gender can be justified by the number of female employees in this activity and also by the character of work (Fig. 2). The proportion of women with recognized occupational disease in the WPI, however, is up to $39 \%$ of all affected workers. This phenomenon can be partly explained by the fact that women are mostly occupied as auxiliary workers in this activity. Their work is often physically demanding, performed under adverse conditions and with a low level of mechanization. This situation has arisen due to the above mentioned facts and because the limits of women physical loading has been disregarded.

The occurrence of specific types of disease was evaluated by activities (Fig. 3) and also by gender (Fig. 4). Most of the diseases present in forestry are diseases caused by vibration -vibration disease of joints, bones, tendons and muscles (2802), disease of blood vessels and nerves (2801) and other vibration diseases and combined diseases caused by vibration (2803). The total share of these three types of diseases is only $52 \%$ of all diseases. This fact may be affected by the proportion of work carried out by machanes affecting the human body by vibration. The occurrence of diseases

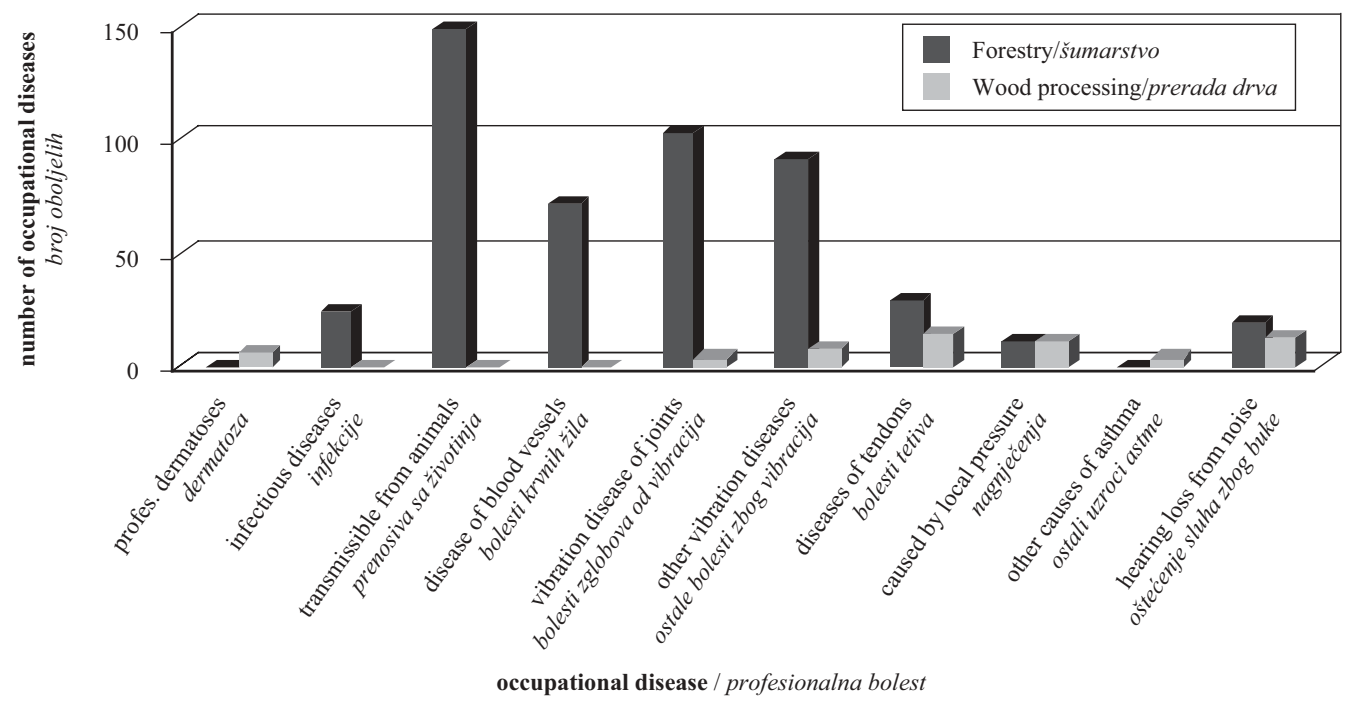

Figure 3 Occurrence of specific diseases classified by activities

Slika 3. Zastupljenost pojedinih profesionalnih bolesti u šumarstvu i drvnoprerađivačkoj industriji 


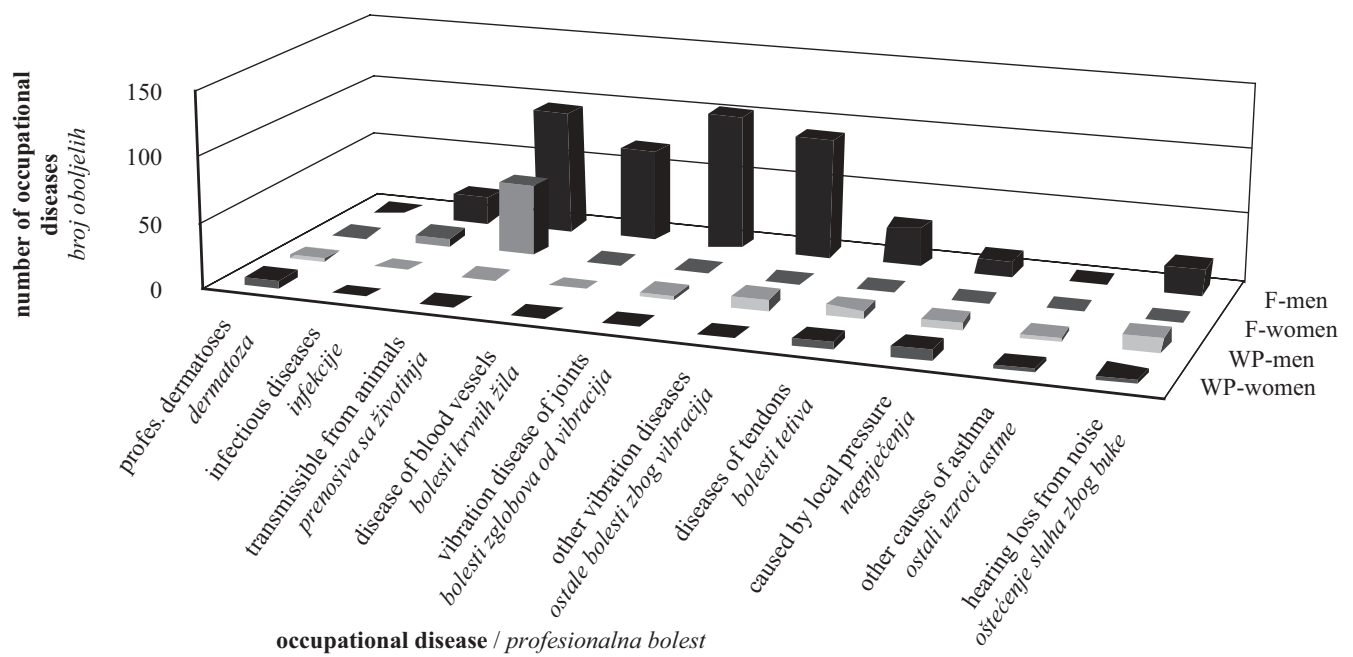

Figure 4 Occurrence of specific diseases in forestry and WPI classified by gender

Slika 4. Zastupljenost pojedinih profesionalnih bolesti u šumarstvu i drvnoprerađivačkoj industriji prema spolu

transmissible from animals to humans either directly or through a vector (2600) is largely influenced by the nature and conditions of workplace. This disease dominates in women working in forestry, as they are mostly the ones who carry out silvicultural activities. In 2009, the disease ,acute carbon monoxide poisoning“ was reccorded in forestry for the first time in the observed period. In specific conditions (dense young vegetation - tending felling and regeneration felling - natural regeneration, respectively) a specific microclimate (enclosed space) develops with little wind, which may lead to contamination of the environment with $\mathrm{CO}_{2}$ when the portable chain saw is used.

Dominant diseases in men in WPI correspond to the overall occurrence of occupational diseases in the WPI, thus mostly hearing is harmed by an excessive noise. The occurrence of diseases defined as other vibration diseases and combined diseases from vibrations (2803), diseases of tendons, tendon sheaths and muscle insertions from excessive overloading (2902) and vibration disease of joints, bones, tendons and muscles (2802) can be characterized as high. Inwomen, the most often recognized disease had the nature of permanent nerve palsy caused by local pressure (2904), then diseases of tendons, tendon sheaths and muscle insertions from excessive overloading (2902) and professional dermatoses caused by other chemicals (organic and inorganic) (2217) follow.

Harmful factors occurring in forestry and woodworking industry, generating an occupational disease, or risk of occupational disease inception, poisoning, etc. are discussed in Figure 5 (Fig. 5). A simple analysis of the occurrence of occupational diseases in forestry indicated the most frequent harmful factor - vibrations. The share of vibrations transmitted to the limbs (machines, tools) (2002000001) accounted for $35 \%$ and the share of mechanical vibrations (2002000000) accounted for almost $10 \%$ of these factors. The WPI had the largest share of harmful factors - repetitive work with unilateral movements (4000020004), a significant share of vibrations transmitted to the limbs (machine, tools) (2002000001) and the noise (continuous noise, inter- rupted noise, noise in liquids) (2001010001). Noteworthy is the share of noise as a harmful factor, because it reached nearly $16 \%$ of all the above factors in wood processing industry and in forestry the noise factor accounted for approximately $2.9 \%$. It can be assumed that the differences are caused by the specific noise spreading in large workshops and in open spaces. In assessing diseases caused by noise, the following factors should also be taken into consideration: noise parameters of machines and equipment, time of exposure to noise, technological and organizational measures, selection of adequate personal protective equipment and their proper use. In open space, it would be appropriate to assess the synergistic effect of weather on the action of vibration and noise as a harmful factor. In order to compare the age of occupational disease recognition in forestry and wood processing industry particular ages were categorized. The maximum in both activities was reflected in the range of 50 to 55 years. The curve describing the development of the occupational disease frequency in dependence on age has the course corresponding to the development shown in the chart (Fig. 6). Statistically, this distribution of frequencies can be characterized as right-asymmetric, i.e.: with the increasing age, the num-

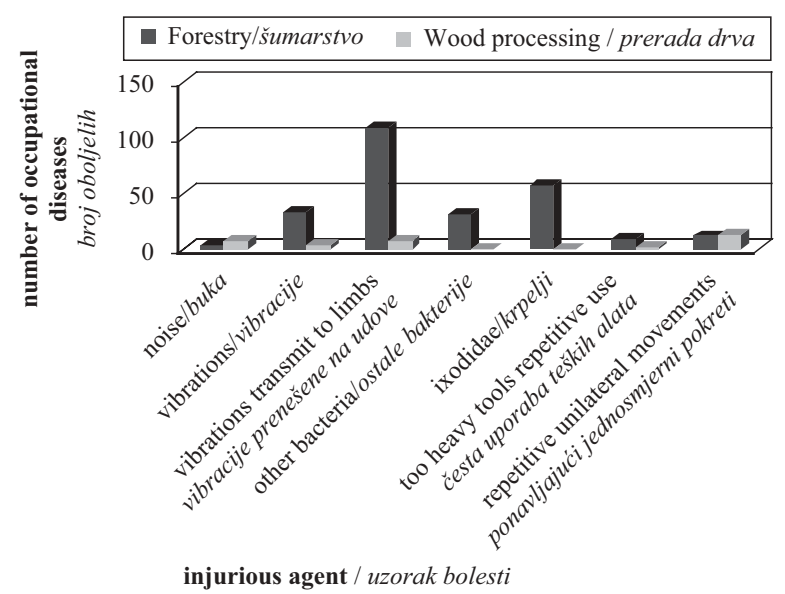

Figure 5 Occurrence of harmful factors

Slika 5. Zastupljenost štetnih činitelja u šumarstvu i drvnoprerađivačkoj industriji 


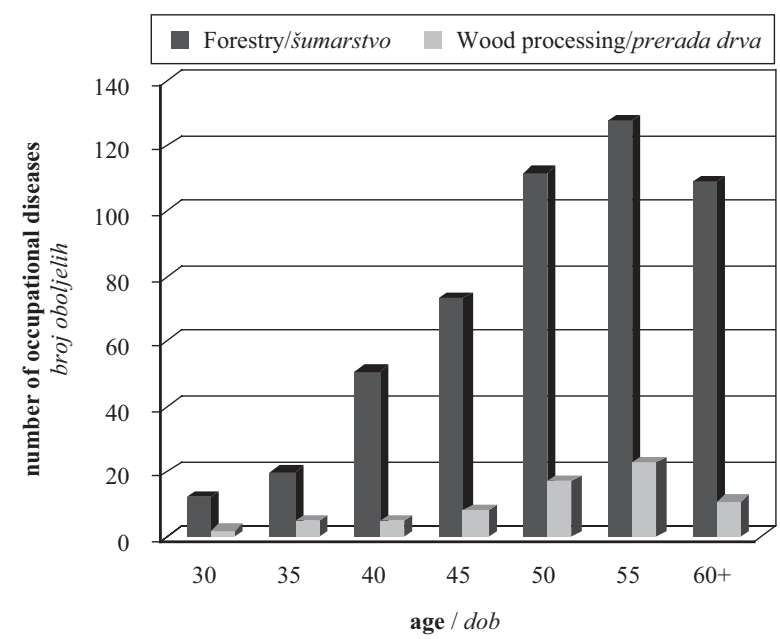

Figure 6 Frequency of occupational diseases in forestry and WPI

Slika 6. Pojavnost profesionalnih bolesti u šumarstvu i drvnoprerađivačkoj industriji prema godinama starosti

ber of recognized occupational diseases goes up. The development of occupational diseases by age is dependent on physical age of the worker, on duration of exposure and on individual susceptibility of the worker to the noise loading.

The same sort of intervals was also used to compare the age of occupational disease recognition classified by gender (Fig. 7). In forestry, in men, the highest number of recognized occupational diseases occurs in the age of 50 to 55 , and there is also a high occurrence in the two adjacent age classes (45-50, 55 + ), where the number of diseases in men working in the WPI also dominates. The culmination of recognized diseases in women is significant in both sectors in the age ranging between 50 and 55 .

It has been possible to evaluate the duration of exposure as a factor influencing the risk of occupational diseases due to a database of information obtained only for the period 2000-2002 and 2005-2009. The chart (Fig.8) shows that the highest frequency of occurrence of occupational diseases in wood processing industry was registered in workers who were exposed for a period of 5 years. This is due to the fact that after 1989 there was an increase of ordinal reconstruction, i.e building of private low-capacity sawmills with saws for primary wood processing with a very simple mechanization. Similarly, work staff was not selected on condition of passing a medical examination at a specialized medicine department or Occupational Medicine Clinic. These conditions have probably led to this result. In forestry, workers who have been exposed to harmful factors for 6 to 10 years during their work are mainly affected. The number of occupational diseases caused by exposure from 11 to 30 years is relatively balanced. This may be affected by a responsible attitude of the employer who, because of the risk of occupational or professional disease, ensures the shift of employees to another position.

In this context, Sowa and Leszczyński (2007) recommend to shorten the exposure time. They established the highest risk of hearing damages in 50 years old workers with a 30-year exposure.

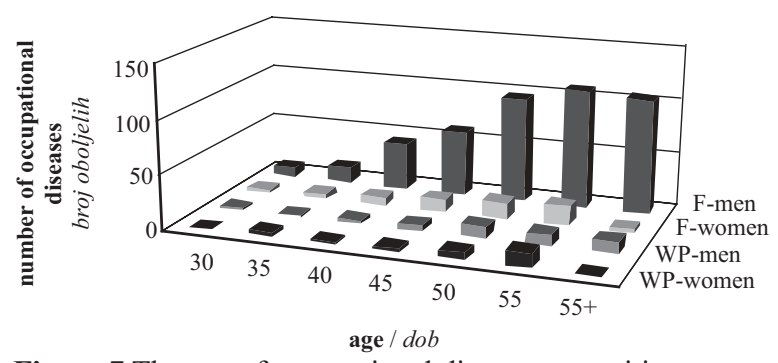

Figure 7 The age of occupational disease recognition classified by gender

Slika 7. Godina prepoznavanja profesionalne bolesti u šumarstvu i drvnoprerađivačkoj industriji prema spolu

The frequency of occupational diseases is completely different, depending on the duration of exposure in men and women (Fig. 9). In the category with the exposure up to 5 years, they had a relatively similar number of recognized diseases. A maximum number of diseases occurred in women, and fewer diseases occurred in men. Based on this result it can be said that the female body has a higher sensitivity to harmful factors, mainly in the early years of exposure to a given factor. For men working in forestry a balanced course of the curve is typical, describing the frequency of occurrence of occupational diseases in dependence on the duration of exposure. And for men working in the WPI, two maximum values were recorded in the category with the exposure from 5 to 10 years and from 30 to 35 years during the observed period.

The analysis of the occurrence of occupational diseases classified by occupation was only possible in two separate parts because of changes in job classification. In the period $2000-2002$ (Fig. 10), the workers in timber logging process (excluding mobile machinery operator) (6142), as well as workers working as operators of sawmills and other equipment for woodworking (8141) and operators of agricultural and forestry machinery (8331) were frequently affected by occupational diseases. A high percentage of occurrences of occupational diseases in timber logging workers is in accordance with a high risk of work and the share of these workers in forestry.

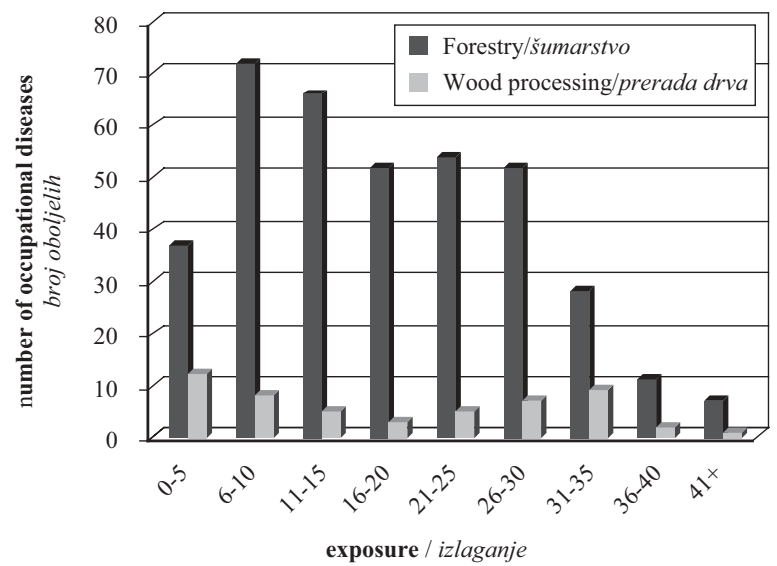

Figure 8 Frequency of occupational diseases in forestry and WPI related to the duration of exposure

Slika 8. Pojavnost profesionalne bolesti u šumarstvu i drvnoprerađivačkoj industriji u odnosu prema trajanju izlaganja 


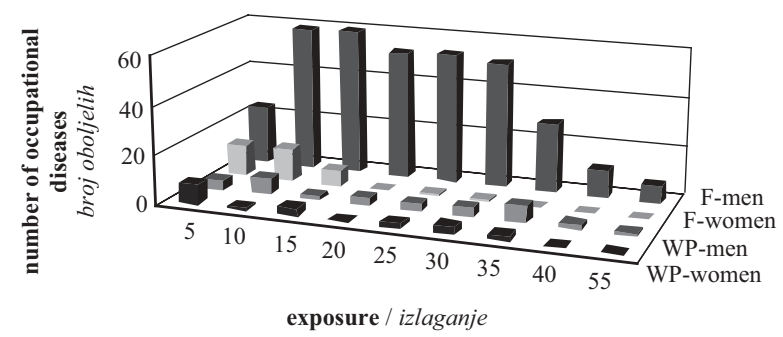

Figure 9 Frequency of occupational diseases related to the duration of exposure and gender

Slika 9. Pojavnost profesionalne bolesti u šumarstvu i drvnoprerađivačkoj industriji prema trajanju izlaganja i spolu

The results of the assessment of occupational diseases in relation to occupation and work nature in the period 2003 - 2008 show that the highest number of recognized diseases was recorded in workers of group 61. This group is made of qualified (skilled) workers working in agriculture, forestry, fishing and hunting. It is the most numerous group of workers with the highest exposure to harmful agents at workplace. The significant risk also occurred in groups 32 (Technicians in biology, medical and agricultural workers and related branches workers) and 92 (Auxiliary and unqualified workers in agriculture, forestry, fisheries and related branches). Affected persons were also recorded in the following professions:

6141 - Workers in silviculture and forest treatment, 9212 - Auxiliary and unqualified forestry workers, 3212 - Technicians in Agronomy, Forestry, Agriculture and Water Management,

71 - Qualified workers at raw material exploitation, builders and employees in close branches (except operators of machines and devices),

83 - Drivers and operators of mobile machinery.

In the woodprocessing industry (Fig. 11) persons employed as operators of woodworking machines and those working in papermill (8149), cabinetmakers, woodcarvers and producers of wood products including the repairers (through the use of simple tools) (7422) and timber harvesting workers (except the mobile plant operators) (6142) were the most affected in the first period (2000-2002). The qualified market oriented workers in agriculture, forestry, fishery and hunting (61) were assessed as the most hazardous professions (with 9 reports) in the second monitored period, they were followed by operators of industry devices (81) with 7 reports and then came the auxiliary and unqualified workers in mines, quarries, industry, building, transport and related sections (93) with 5 reports. Other affected person's professions were:

7123 - Carpenters and cabinetmakers,

8141 - Operators of saw and other wood processing devices,

8240 - Operators of automatic and semi-automatic woodworking machines (except machine setters),

8285 - Assembly workers mounting wood and wood based products,

74 - Other qualified processors and makers, else unmentioned (except machine and device operators),

82 - Operators of stationary devices and assembly workers,

91 - Auxiliary and unqualified employees oriented to distribution and service,

92 - Auxiliary and unqualified employees in agriculture, forestry, fishing and kindred profession,

99 - Unclassified or unknown.

The above mentioned method of the Contingency Tables (Tab. 2) has been used for statistical evaluation of dependency on its degree in the case of qualitative indicators: for the duration of exposure and number of occupational diseases in men and women in forestry and wood processing industry.

The formulation of the null hypothesis: there is no correlation between duration of exposure and the

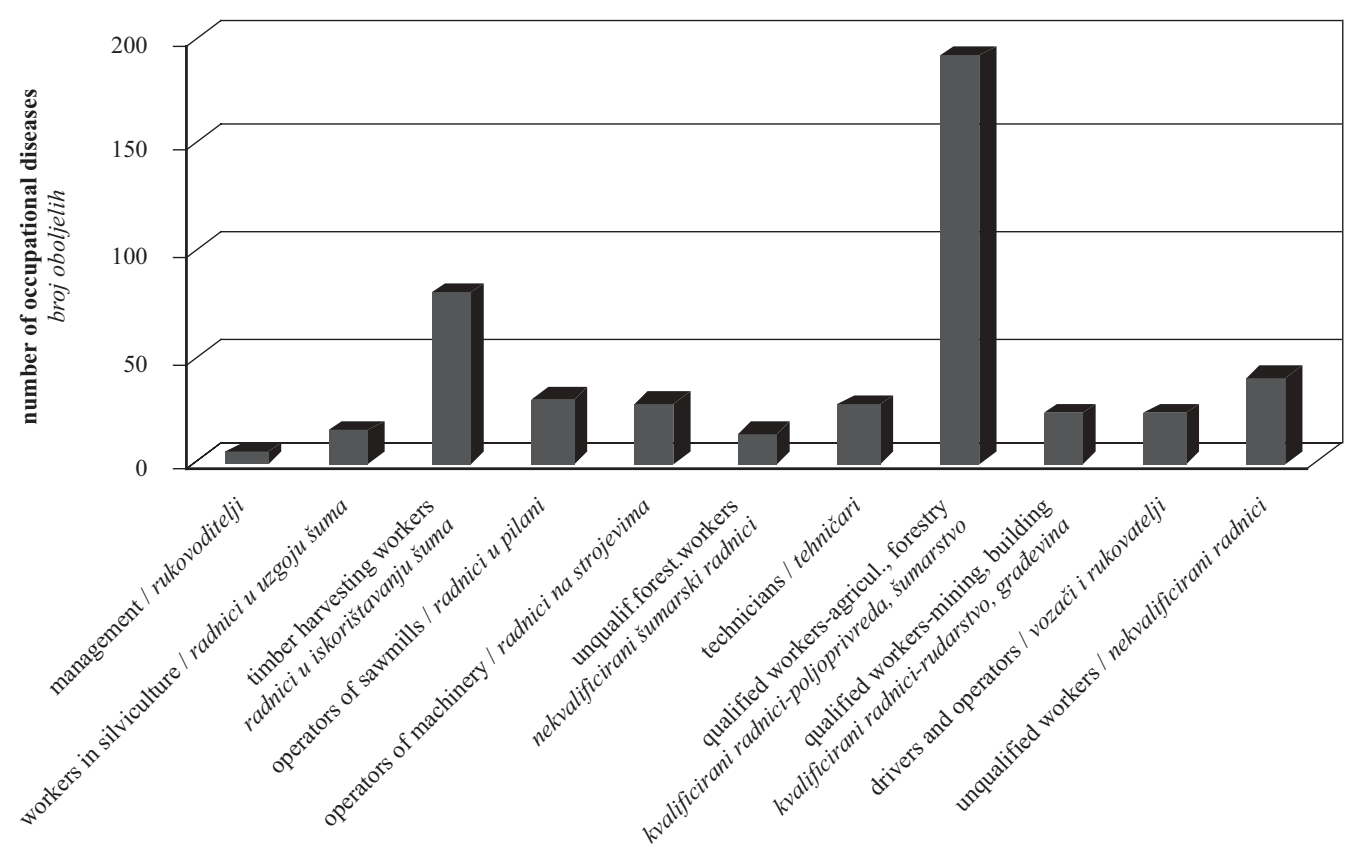

affected person's profession / zanimanje oboljelih

Figure 10 Frequency of occupational diseases in forestry in relation to the affected person's profession Slika 10. Pojavnost profesionalne bolesti u šumarstvu prema radnome mjestu oboljelih 


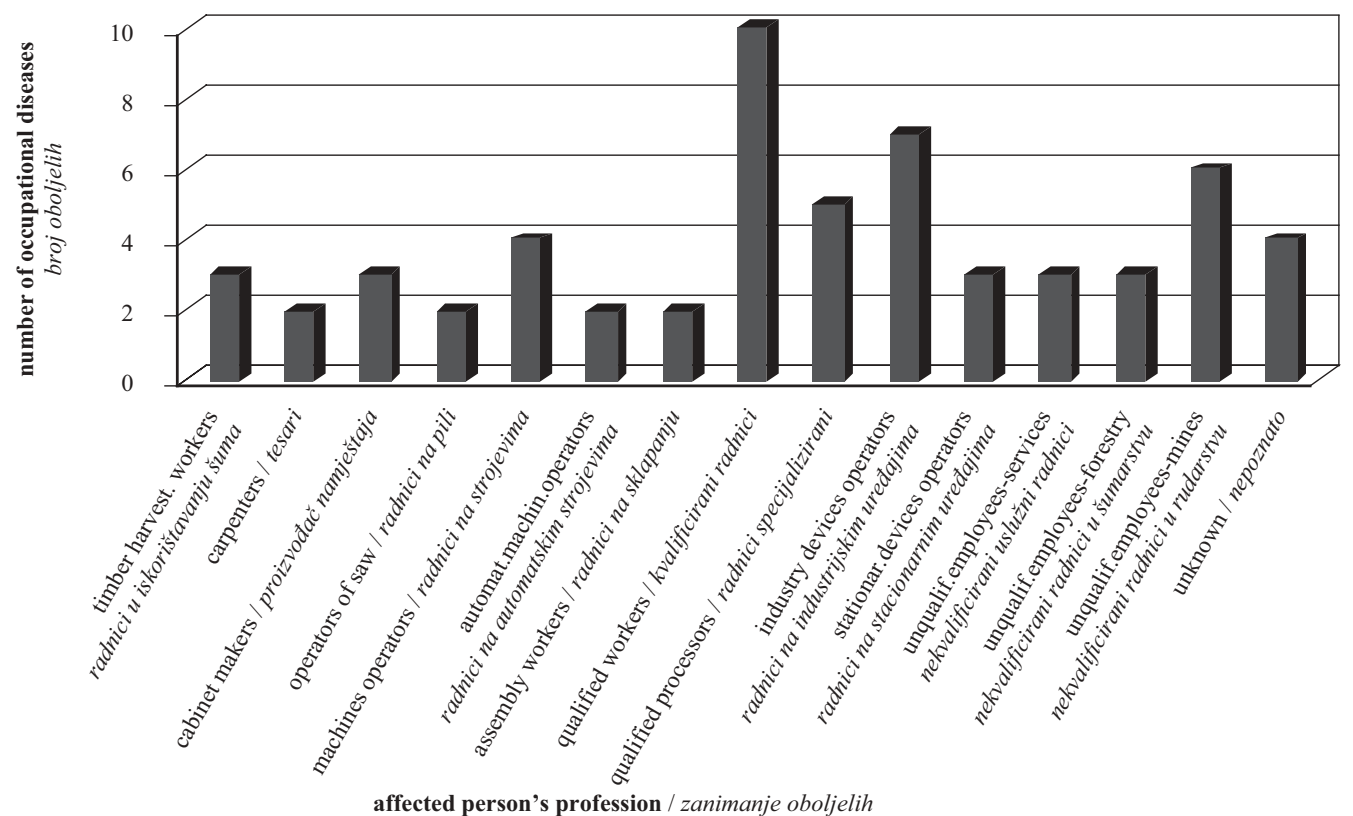

Figure 11 Frequency of occupational diseases in WPI related to the affected person's profession

Slika 11. Pojavnost profesionalne bolesti u drvnoprerađivačkoj industriji prema radnome mjestu oboljelih

occurrence of occupational disease in men and women in forestry and WPI.

With the $5 \%$ significance level and the degree of freedom 2 , the chi square tabulated value is represented by $6.0\left(\chi^{2}<\chi_{2(0.05)}^{2}\right)$, thus it can be concluded that the presented hypothesis is rejected with $95 \%$ probability. The significant differences were observed in the interval with the duration of exposure up to 5 years, when the men reported the lowest occurrence of occupational diseases. The women, with regard to the range of specified intervals, represent the category with the highest occurrence of occupational diseases. This argument confirms the different sensibility of men and women and also the varying intensity of harmful factors activity.

$r_{A B}=0.28953703$

The dependence existing between the occurrence of occupational diseases, or professional diseases in men and women, in relation to the duration of exposure can be defined as poor.

The application of the Contingency Tables method also allows the evaluation of the correlation between the industrial deafness, vibration disease and workers' age (Tab. 3).

Table 2 Number of occupational diseases in men and women in relation to the exposure duration

Tablica 2. Broj profesionalnih bolesti muškaraca i žena u odnosu prema trajanju izlaganja

\begin{tabular}{|c|c|c|c|}
\hline \multicolumn{4}{|c|}{ Occupational diseases / Profesionalna oboljenja } \\
\hline $\begin{array}{l}\text { Exposure duration } \\
\text { Trajanje izlaganja }\end{array}$ & $\begin{array}{c}\text { Men } \\
\text { Muškarci }\end{array}$ & $\begin{array}{c}\text { Women } \\
\text { Žene }\end{array}$ & $\Sigma$ \\
\hline \multirow{2}{*}{$\begin{array}{l}\text { up to } 5 \text { years } \\
\text { do } 5 \text { godina }\end{array}$} & 28 & 21 & \multirow[t]{2}{*}{49} \\
\hline & 42.97447796 & 6.025522 & \\
\hline \multirow{2}{*}{$\begin{array}{l}5-20 \text { years } \\
5-20 \text { godina }\end{array}$} & 183 & 23 & \multirow[t]{2}{*}{206} \\
\hline & 180.6682135 & 25.33179 & \\
\hline \multirow{2}{*}{$\begin{array}{l}\text { more than } 20 \text { years } \\
\text { više od } 20 \text { godina }\end{array}$} & 167 & 9 & \multirow[t]{2}{*}{176} \\
\hline & 154.3573086 & 21.64269 & \\
\hline$\Sigma$ & 378 & 53 & 431 \\
\hline
\end{tabular}

Table 3 Correlation between industrial deafness, vibration disease and workers' age

Tablica 3. Korelacija između industrijske gluhoće, bolest zbog izlaganja vibracijama i godina starosti

\begin{tabular}{|l|c|c|c|}
\hline \multicolumn{4}{|l|}{ Occupational diseases / Profesionalne bolesti } \\
\hline $\begin{array}{l}\text { Age / } \\
\text { Godine } \\
\text { starosti }\end{array}$ & $\begin{array}{c}\text { Industrial deafness / } \\
\text { Industrijska gluhoća }\end{array}$ & $\begin{array}{c}\text { Vibration disease / } \\
\text { Bolesti zbog } \\
\text { vibracija }\end{array}$ & \\
\hline \multirow{2}{*}{$24-44$} & 2.5 & 68.5 & \multirow{2}{*}{71} \\
\cline { 2 - 4 } & 7.352750809 & 63.647249 & \\
\hline \multirow{2}{*}{$45+$} & 29.5 & 208.5 & 238 \\
\cline { 2 - 4 } & 24.64724919 & 213.35275 & \\
\hline$\Sigma$ & 32 & 277 & 309 \\
\hline$\chi^{2}=4.638594 ;$ Degree of freedom (DF): 1 & \\
\hline
\end{tabular}

The formulation of the null hypothesis: there is no correlation between age and occurrence of industrial deafness and vibration disease. As one of the frequencies in the contingency table was less than 5, the Yates correction was applied.

The critical value of chi square for the $1^{\text {st }}$ degree of freedom and significance level $\alpha=5 \%$ is $\chi_{1(0.05)}^{2}=$ 3.8. As the calculated value of $\chi^{2}(4.64)$ is greater than the tabulated critical value, it can be said with $95 \%$ probability that the presented hypothesis is rejected.

The coefficient of association $r_{A B}=0.122522$ characterizes the dependence between age and deafness and vibration disease occurrence as weak.

\section{CONCLUSIONS 4. ZAKLJUČCI}

Although nowadays a variety of jobs are provided, where human presence may be almost completely eliminated, there are still occupations in which the human factor dominates for many reasons. Despite of preventive measures and compliance with safety and health at work, it is not possible to prevent occupational diseases and professional diseases, respectively. 
The analysis of results showed that the occurrence of diseases recorded during the last reporting period is not negligible either. There is a high proportion of diseases in women in WPI, which reaches nearly $40 \%$, while in forestry men are mostly affected. The most frequent disease in forestry is the vibration disease. The total share of the three types of the vibration disease amounts to $52 \%$ of all diseases.

In the wood processing industry, the damage to hearing was the most frequent disease. In forestry, men and women in the same age group - 50 to 55 were the most frequently affected. The same is true for women working in the WPI; in men working in this sector most diseases were found in the last three categories, i.e. age above 45 years. Based on the available data, it can be concluded that the number of deceases developed differently depending on the duration of exposure and gender in both sectors, but most diseases occurred in workers exposed to short-term exposure (up to 10, i.e. 5 to 15 years - men in forestry). Men who work in WPI are an exception, as two maxima in the frequency chart of diseases were found there. In forestry, workers in timber logging process (except mobile equipment operators) are most highly affected by occupational diseases, i.e. workers assigned to a group of skilled workers in agriculture, forestry, fishing and hunting. In theWPI, the affected persons are those employed in other service facilities for wood and paper mills, such as skilled market oriented workers in agriculture, forestry, fishing and hunting.

One of the main factors influencing the development of occupational diseases in Slovakia is the disintegration of the health care system. This is obvious mainly in the neglected preventive health examinations, where it is often possible to identify a threat from an occupational disease. Only a few companies organize convalescent stays for their workers. Mainly in forestry, the development of occupational diseases was crucially influenced by the fact that the work is provided by contractors. The basic legislative rule relating to the Health and Safety at workplace in Slovakia (National Council of Slovak Republic No. 124/2006 Coll. on health and safety at work and amendments thereof) only refers to employees, but does not address the issue of HSW among traders and self-employed persons. Therefore, it is necessary to initiate a change in legislation that would include ensuring the safety and health of sole traders mainly in terms of organization, control and consequences solution.

\section{Acknowledgments - Zahvala}

This work was supported by the Slovak Research and Development Agency based on the Contract No. LPP-0420-09 "Analysis of safety, health and hygiene risks in the processing of forest biomass for energy purposes“", the Ministry of Education, Science, Research and Sport of the Slovak Republic by the grant project VEGA 1/0764/10 "Precision forestry principles and methods research" and the Ministry of Education Agency for the structural EU funds by the project RELAZ Applied research and development of special ca- ble equipment - special skyline carriage (ITMS Project code: 26220220036) and Project II RELAZ Applied research and development of special cable equipment - special flywheel (ITMS Project code: 26220220035).

\section{REFERENCES}

\section{LITERATURA}

1. Beljo Lučić, R.; Goglia, V., 2001: Some possibilities of reducing circular saw idling noise. Journal of Wood Science, 47 (2001): 389-393, http://dx.doi.org/10.1007/ BF00766791

2. Dzurenda, L. et al., 2010: The effect of thermal modification of oak wood on the sawdust granularity. Drvna industrija, 61 (2):

3. Goglia, V., Grbac, I., 2005: Whole-body vibration transmitted to the frame saw operator. Applied ergonomics 36 (2005): 43-48, http://dx.doi.org/10.1016/j.apergo.2004.09.005

4. Goglia, V., Žgela, J., 2003: Promjene razina vibracija na ručkama motornih pila lančanica. (Changes in the Vibration Level on the Chain Saw Handles). Rad i sigurnost 7 (2); 77-90.

5. Irša, A.: Zákernýprach[online]. [cit. 2010-03-24]. http:// www.rezbarstvo.sk/index.php?option=com_content\&task $=$ view\&id=119\&Itemid $=1$

6. Klč, P., Radocha, M., 1998: Analýzy vybraných výsledkov ergonomických meraní Zraňovacej pôdnej frézy typ ZPF-500. Lesnícky časopis - Forestry journal, 44(3): $149-158$.

7. Myslivec. V., 1957: Statistické metody zemědělského a lesnického výzkumnictví. SZN Praha.

8. Sowa, J. M., Leszczyński, K., 2007: Zagrożenie akustyczne operatorów maszyn podczas pozyskiwania drewna. Prace z zakresu nauk rolniczych i lesnych, 233-240.

9. Suchomel, J., Belanová, K., 2009: Projekt APVV LPP0420-09. In: Multi operačné výrobné technológie prit’ǎbe a spracovaní dendromasy na energetické a priemyselné využitie, 165-168.

10. Šmelko, ŠS., Wolf, J., 1977: Štatistické metódy v lesníctve. Príroda Bratislava: $330 \mathrm{pp}$.

11. Šmelko, Š., 1998: Štatistické metódy v lesníctve. TU Zvolen, Zvolen, p. 276.

12. Štatistický úrad Slovenskej republiky: Vývojvy braný chukazovatel'ov o pracovnej neschopnosti prechorobu a úraz v Slovenskej republike (2002-2008) [online]. [cit. 2010-03-24].http://portal.statistics.sk/showdoc.do?docid $=14974$

13. Trenčiansky, M., Lieskovský, M., Oravec, M., 2007: Energetické zhodnotenie biomasy. NLC Zvolen, 147.

14. Wellborn, S. N.: Health Hazards in Woodworking [online]. [cit. 2010-03-23]. http://www.taunton.com/finewood working/Workshop/WorkshopPDF.aspx?id=2013

\section{Corresponding address:}

Assoc. Prof. JOZEF SUCHOMEL, Ph.D.

Department of Forest Exploitation and Mechanisation Faculty of Forestry

Technical University of Zvolen

Masarykova 24

96053 Zvolen, SLOVAKIA

e-mail: suchomel@vsld.tuzvo.sk 